\title{
RIBA VS ZAKAT DALAM PERPEKTIF EKONOMI ISLAM
}

\author{
Iwan Romadhan Sitorus \\ IAIN Bengkulu \\ Email: iwansitorusmedan@gmail.com
}

\begin{abstract}
The main characteristic of Islamic economics compared to the conventional economy is the prohibition on taking usury or interest in each transaction. The use of other people's assets in an unfair way, in the form and through any means, is prohibited in the Qur'an. Usury which is interpreted as an addition, definitively involves consuming (eating) the wealth of others in a physical way. Usury is directly opposite the cooperative spirit in Islamic teachings. People who are rich, in Islamic teachings, are required to give the rights of the poor by paying zakat and then giving alms in addition to the zakat. Islam does not allow Muslims to make their wealth a vehicle for sucking the blood of poor people. Al-Qur'an letter Ali Imran verse 130 states that happiness (falah) will be obtained by abandoning this usury system, and at the same time the Qur'an states that happiness cannot be obtained through ribawi practice. Because usury is based on injustice.
\end{abstract}

Keywords: Usury, Zakat, Perspective, Economy, Islam

Abstrak :Ciri ekonomi Islam yang utama dibandingkan dengan ekonomi konvensional adalah adanya larangan mengambil riba atau bunga (interest) dalam setiap transkasi. Penggunaan harta orang lain dengan cara yang tidak adil, dalam bentuk dan lewat cara apapun, adalah dilarang di dalam Al-Qur'an. Riba yang diartikan sebagai tambahan, secara definitif mencakup mengkonsumsi (memakan) kekayaan orang lain dengan cara yang bathil. Riba sangat berseberangan secara langsung dengan spirit kooperatif yang ada dalam ajaran Islam. Orang yang kaya, dalam ajaran Islam, diharuskan untuk memberikan hak-hak orang miskin dengan cara membayar zakat dan kemudian memberikan sedekah sebagai tambahan dari zakat itu. Islam tidak mengizinkan kaum muslimin untuk menjadikan kekayaannya sebagai kendaraan untuk mengisap darah orang-orang miskin. Al-Qur'an surat Ali Imran ayat 130 menyatakan bahwa kebahagian (falah) itu akan diperoleh dengan cara meninggalkan sistem riba ini, dan pada saat yang sama Al-Qur'an menyatakan bahwa kebahagiaan tidak mungkin akan diperoleh lewat praktek ribawi. Karena riba itu berdasar pada ketidakadilan.

Kata Kunci : Riba, Zakat, Perspektif, Ekonomi, Islam

\section{A. PENDAHULUAN}

Zakat merupakan salah satu pilar dari pilar Islam yang lima. Allah SWT telah mewajibkan bagi setiap muslim untuk mengeluarkannya sebagai penyuci harta mereka, yaitu bagi mereka yang telah memiliki harta sampai nishab (batas terendah wajibnya zakat) dan telah lewat atas kepemilikan harta tersebut masa haul (satu tahun bagi harta simpanan dan niaga, atau telah tiba saat memanen hasil pertanian). Sedangkan riba merupakan sistem penghancur ummat, ekonomi juga budaya Islam. Sistem telah terbentuk, caraterbijak adalah dengan sangat meminimalisir segala yang berhubungan dengan riba, jangan jadikan ia sebagai pola hidup, dan budayakan kembali ekonomi Islam. Dengan demikian, antara zakat dan riba mempunyai perbedaan yang tidak dapat disatukan.

Zakat yang di fahami selama ini berarti tumbuh, suci. Dan riba bermakna $a z$ ziyadah (bertambah). Tetapi makna yang telah di definisikan oleh fuqaha' berbeda dengan yang terjadi dilapangan. Masyarakat memahami bahwa zakat berarti mengurangi harta yang di miliki. Sebab, 
jika seseorang yang telah diwajibkan Allah

SWT untuk mengeluarkan zakatnya, maka secara otomatis berkurang. Padahal kenyataan yang sebenarnya tidak demikian. Menurut yang mengeluarkan harta berkurang tetapi disisi Allah bertambah. Hal ini sangat bertolak belakang dengan riba. Masyarakat memahami bahwa apabila seseorang yang ingin menabungkan uangnya yang di imingi-imingi dengan bunga, maka menurut mereka itu akan bertambah. Padahal fakta yang sebenarnya, tidak demikian. Menurut si penabung bertambah, tetapi di sisi Allah SWT tidak bertambah.

\section{B. PENGERTIAN RIBA DAN ZAKAT}

Riba secara bahasa riba berarti tambahan.Sedangkan secara terminologis riba adalah tambahan yang diambil oleh pemberi hutang dari penghutang sebagai perumbangan dari masa (meminjam). ${ }^{1} \mathrm{Al}$ Jurjani mendefiniskan riba sebagai tambahan atau kelebihan yang tiada bandingannya bagi salah satu orang yang berakad. ${ }^{2}$ Sementara Abdurrahman al-Jaziri dalam Kitāb al-Fiqh alā MadzāhibalArbaah menjelaskan bahwa riba menurut

\footnotetext{
${ }^{1}$ Muhammad Ali al-Shabuni, Rawā"i, alBayān Tafsīr Ayāt al-Ahkām min al-Qur"ān, jilid 1, Beirut: Dār al-Fikr, t.tt., hlm. 383

${ }^{2}$ Ali bin Muhammad al-Jurjani, Kitab alTa, rifāt, Beirut: Dār al-Kutub al-,Ilmiyyah, t.tt., hlm. 109
}

istilah fuqaha adalah tambahanpada salah satu dua barang yang sejenis yang ditukar tanpa adanyaimbalan/imbangan terhadap tambahan tersebut. ${ }^{3}$ Dalam madzhab Syafie $^{\text {ee }}$, ribadimaknai sebagai transaksi dengan imbalan tertentu yang tidak diketahuikesamaan takarannya maupun ukuran waktunya kapan terjadi transaksi denganpenundaan penyerahan kedua barang yang dipertukarkan atau salah satunya. ${ }^{4}$

\section{METODE PENELITIAN}

Jenis metode penelitian ini adalah kepustakaan (library research), yaitu mengumpulkan beberapa literatur yang berkaitan dengan masalah-masalah yang akan di bahas dan yang akan dijadikan bahan acuan dalam penulisan ini. Dengan penelitian melalui kepustakaan, kitab-kitab yang berkaitan dengan perekonomian Islam, sumber-sumber penunjang yang lain diantaranya tafsir Al-Quran, buku-buku yang berkaitan dengan perspektif ekonomi Islam dan ekonomi konvensional, dan yang ada kaitannya dengan masalah yang akan dibahas dalam pembahasan ini. 
D. AYAT PENGHARAMAN RIBA

1. Surah ar-Rum (30): 39, Surah anNissa' (4): 160-161, dan Surah AliImran (3): 130

a. Teks Ayat dan Terjemahnya

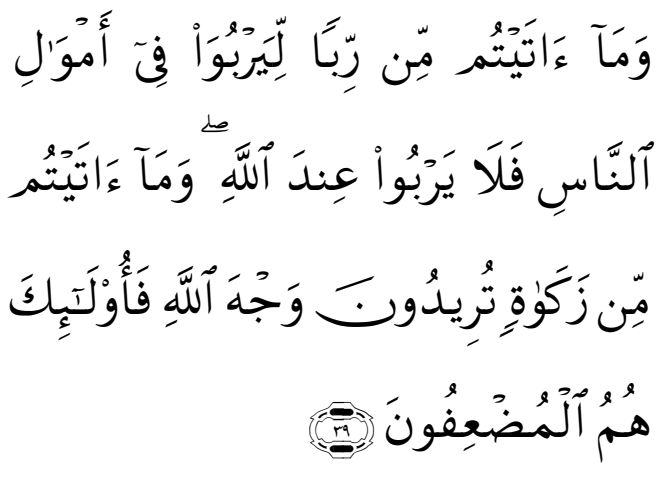

Artinya:"Dan sesuatu Riba (tambahan) yang kamu berikan agar Dia bertambah pada harta manusia, maka riba itu tidak menambah pada sisi Allah. dan apa yang kamu berikan berupa zakat yang kamu maksudkan untuk mencapai keridhaan Allah, maka (yang berbuat demikian) Itulah orangorang yang melipat gandakan (pahalanya).” (QS. Ar-Rum (30): 39)

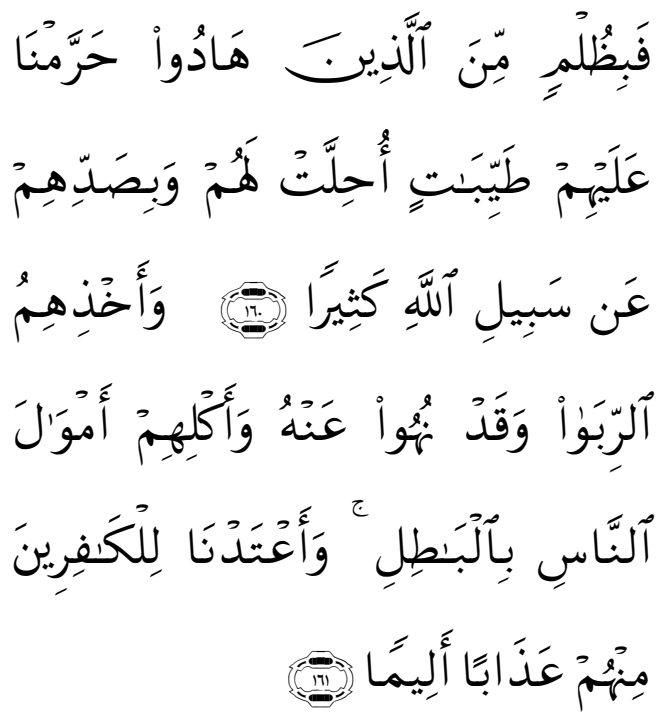

Artinya: "Maka disebabkan kezaliman orang-orang Yahudi, Kami haramkan atas (memakan makanan) yang baik-baik (yang dahulunya) dihalalkan bagi mereka, dan karena Mereka banyak menghalangi (manusia) dari jalan Allah." (160). "Dan disebabkan mereka memakan riba, Padahal Sesungguhnya mereka telah dilarang daripadanya, dan karena Mereka memakan harta benda orang dengan jalan yang batil.Kami telah menyediakan untuk orangorang yang kafir di antara mereka itu siksa yang pedih”.(161) (QS. An-Nissa (4))

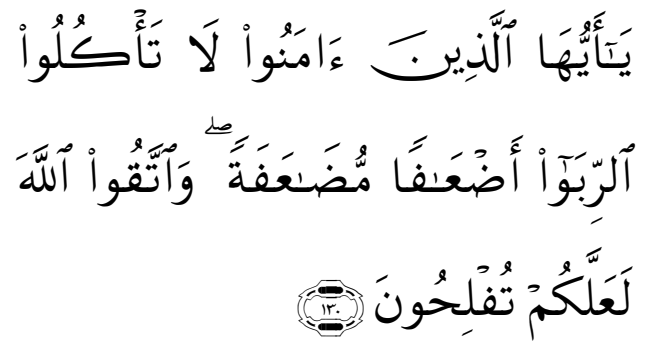

Artinya: "Hai orang-orang yang beriman, janganlah kamu memakan Riba dengan berlipat ganda dan bertakwalah kamu kepada Allah supaya kamu mendapat keberuntungan. (QS. Ali-Imran (3): 130)

\section{b. Makna Global}

Seperti disinggung sebelum ini, bahwa pengharaman riba itu melalui proses yang cukup panjang; tidak serta-merta apalagi dengan tiba-tiba. 
Proses yang dimaksudkan adalah: mula-mula Allah mengingatkan dampak buruk dari riba yang diperbuat oknum-oknum Yahudi dan lainnya yang memandang tambahan perolehan melalui cara-cara eksploitasi pihak lain (riba) itu bukanlah pertumbuhan dan penambahan ekonomi yang baik, sebagaimana halnya dengan pertumbuhan dan pertambahan yang diperoleh melalui zakat yang kemasannya karena mengharapkan ridha Allah. Sedangkan pertambahan dan pertumbuhan ekonomi dan keuangan yang berbasiskan riba yang didorong oleh kerakusan terhadap harta, cepat atau lambat justru akan melemahkan pertumbuhan dan pertambahan (kenaikan) ekonomi dan keuangan. Sampai di sini, Al-Quran masih belum menyatakan keharaman riba, mengingat peringatannya hanya dalam bentuk isyarat tentang ketidakşukaan (kebencian) Allah kepada praktik riba itu.Ayat ini baru berisikan nasihat yang bersifat pengingkaran atau negatif terhadap praktik riba (mau'izhah salbiyyah).

Ketika sindiran Surah Ar-Rûm (30) ayat 39 di atas tetap tidak pernah digubris oleh pelaku-pelaku riba, maka Allah memberikan peringatan berikutnya yang lebih jelas lagi dengan menurunkan ayat yang membuka kedok oknum-oknum Yahudi yang masih tetap mempraktikkan riba meskipun sudah diharamkan. Hanya saja, pengharaman riba ini oleh ahli-ahli tafsir dipahami sebagai pengharaman yang bersifat semacam catatan peringatan (al-talwîh), belum sampai ke tingkat yang lebih jelas (altashrîh). Ayat ini pada dasarnya masih sama dengan ayat yang bernuansa dialogis tentang dampak negatif khamr dan maisir sebagaimana terdapat dalam Surah al-Baqarah (2): 219 yang mendiskusikan atau memperdebatkan ihwal dampak positif dan negatif dari khamr (minuman keras) dan maisir (judi).

Pengharaman riba secara nyata, baru dilakukan pada periode berikutnya tatkala Allah menurunkan ayat 130 Surah Ali `Imrân (3): 130 yang sudah dikutipkan di atas. Hanya saja, pengharaman riba di dalam ayat ini, juga belum bersifat menyeluruh (kulli), melainkan hanya bersifat 
sebagian (juz,i) mengingat masih ada kesan dan prasyarat bahwa riba yang diharamkan itu hanyalah riba yang berlipat-ganda (adh'afan mudha'afah). Sedangkan riba yang tidak berlipat-ganda, kesannya seolah-olah tidak diharamkan. Pengharaman riba yang bersifat $j u z^{\prime} i$, ini laksana suasana pengharaman khamr dan maisir yang terkandung dalam Surah al-Baqarah (2): ayat 219, yang benar-benar mengandung perdebatan panjang dan alot, tetapi sangat objektif dan produktif mengingat penurunan ayatnya yang dilakukan sepotong demi sepotong, dalam rangka memberikan kesempatan kepada para pemburu riba sebagaimana para "pecandu" khamr dan maisir supaya melakukan perenungan lebih jauh (mendalam) tentang dampak negatif yang ada pada riba sebagaimana dampak negatif yang ada pada khamr dan maisir yang bahayanya jauh lebih besar daripada manfaatnya.

Mirip dengan kasus pengharaman khamr dan maisir yang melalui proses agak panjang dan alot, pengharaman riba secara mutlak baru dilakukan melalui Surah al-Baqarah
(2): 275-281 yang akan dibahas secara tersendiri sesudah ini.

\section{c. Tafsir Ayat}

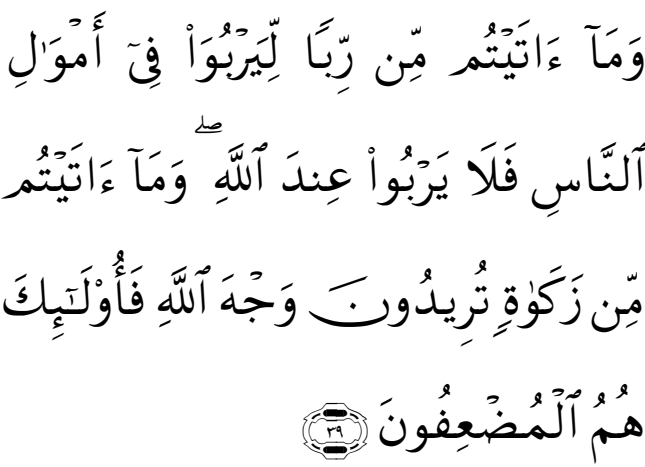

Artinya : "Yaitu, dan apa-apa yang telah kalian berikan dari harta-harta kalian (orangorang kaya) melalui praktikpraktik riba, dengan maksud supaya kalian menambah atau memperbanyak hartaharta kalian, maka sesungguhnya itu tidak akan bertambah, tidak akan bersih, dan tidak mungkin akan menjadi berlipatganda menurut pandangan Allah, karena bagaimanapun praktik riba itu adalah perilaku (ekonomi) buruk yang tidak akan diberkahi oleh Allah"(Qs. Ar-Rum:39)

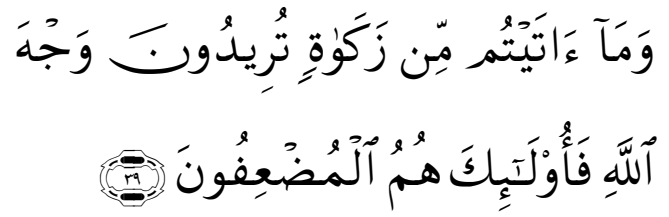

Artinya : "Dan sebaliknya, apa (harta) yang kalian berikan dari harta-harta zakat yang tidak seberapa yang kalian keluarkan karena mengharapkan keridhaan Allah"(Qs.Ar-Rum:39) 
Sesungguhnya harta-harta (zakat) yang demikian itulah yang akan mengalami pertumbuhan dan perkembangan yang berlipat-ganda. Dengan kalimat lain, pelipatgandaan harta kekayaan yang dilakukan dengan mempersubur riba, dipastikan tidak akan tercapai karena laksana buih atau debu yang ada di atas bebatuan yang kemudian terkena air hujan. Sebaliknya, pelipatgandaan harta kekayaan yang sejati itu adalah yang dilakukan dengan melalui caracara zakat, infak, dan sedekah yang pelipatgandaannya dijamin Alquran.Termasuk pelipatgandaan penghasilan di samping pelipatgandaan pahalanya yang bisa mencapai antara sepuluh hingga tujuh ratus kali lipat.

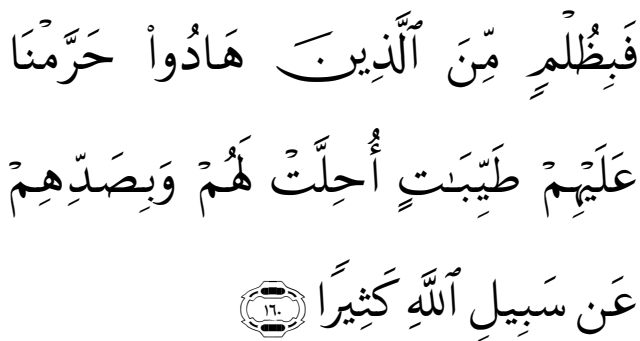

Artinya : "Yaitu, dan disebabkan kemusyrikan orang-orang Yahudi itulah maka Kami (Allah) mengharamkan beberapa jenis konsumsi yang semula sesungguhnya dihalalkan buat mereka, misalnya binatang yang berkuku, gajih sapi maupun kambing yang dahulunya dihalalkan buat mereka. Pengharaman itu juga disebabkan mereka sering menghalang-halangi orang lain dari penegakan agama Allah"(Qs.An-Nisa:160)

Penyebab lainnya bagi pengharaman beberapa jenis makanan kepada mereka (orangorang Yahudi), itu adalah karena mereka menarik (memungut) riba yang sesungguhnya sudah diharamkan kepada mereka sebagaimana termaktub (di dalam Taurat). Mereka juga memakan harta orang lain dengan melalui cara-cara yang batil, semisal suap, pemerasan, dan penipuan. Dan, sebagai balasannya, Kami (Allah) telah menyiapkan siksaan yang sangat dahsyat bagi orang-orang yang kafir di antara mereka itu.

\section{d. Istinbat Ayat}

Sebagaimana disebutkan sebelum ini, bahwa ketiga ayat di atas memuat rangkaian proses pelarangan dan kemudian pengharaman riba yang sangat mengganggu kehidupan ekonomi dan keuangan masyarakat bahkan bangsa dan negara. Mulanya melalui Surah Ar-Rum (30) ayat 39, Allah memberitahukan praktik busuk 
jual-beli (perdagangan) yang sarat dengan rekayasa dan bahkan tipu daya dengan motif mencari keuntungan sebanyak-banyaknya dengan menggunakan modal sekecilkecilnya.Karena tidak mampu melakukan jualbeli secara tunai, maka bentuk jual-beli diubah dengan utang-piutang (kredit) sampai waktu yang ditentukan.Akan tetapi, dalam pelaksanaan selanjutnya jika perlu boleh diperpanjang jatuh tempo utang-piutang itu dengan syarat memberikan bayaran tambahan.Celakanya selain harus membayar utang pokok, juga harus membayar uang tambahan yang disebut dengan "bunga" atau "interest". Karena berkali-kali, menjadi bunga-berbunga, maka nilai utang pun kian waktu semakin membumbung dan berlipat-ganda. Bunga berlipatlipat itulah yang diistilahkan Alquran dengan adh'afan mudh'fatan, yang dalam hadis disebut dengan riba nasi'ah.

Memerhatikan, menyaksikan, dan merasakan bahaya laten riba karena hanya memperkaya-raya segelintir orang, pengusaha, bangsa, dan negara tertentu, maka Al-Quran melalui
Surah al-Baqarah yang segera akan dibahas setelah ini menyatakan perang terhadap praktik ekonomi dan keuangan yang berbasiskan ribawi, apa pun bentuk dan nama serta bagaimanapun praktiknya.

2. Surah al-Baqarah (2): ayat 275-276

\section{a. Teks Ayat dan Terjemahnya}
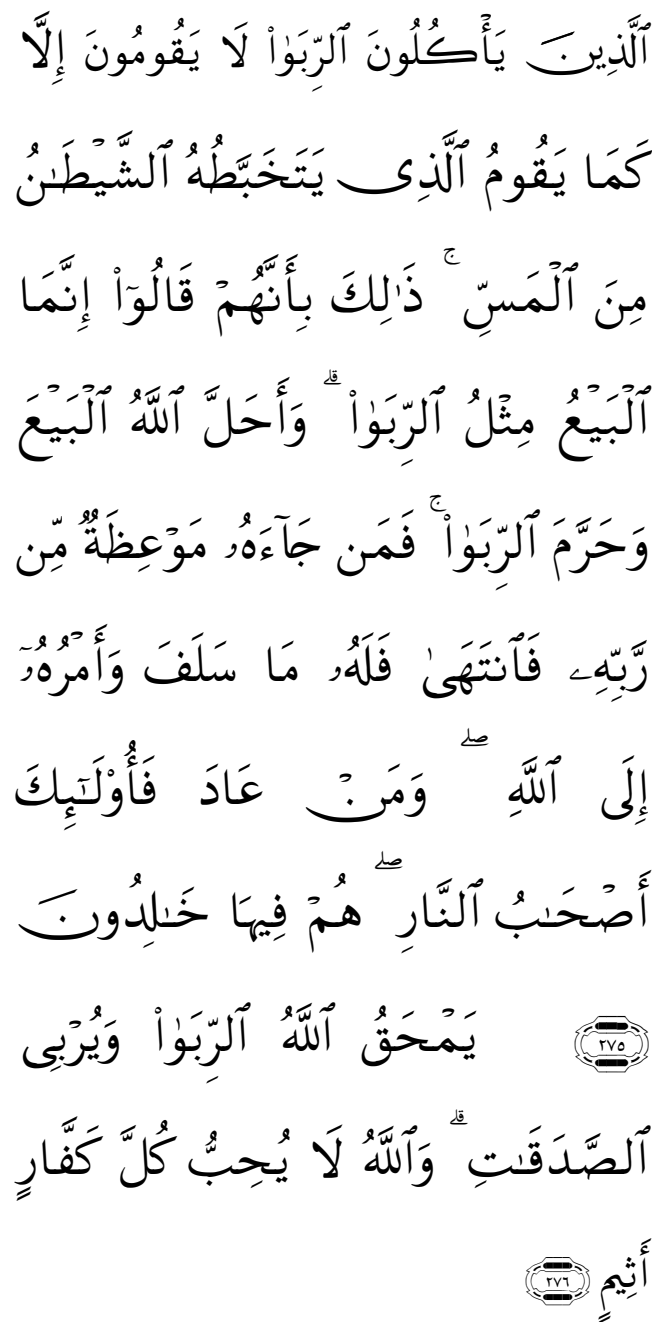

Artinya : "Orang-orang yang Makan (mengambil) riba tidak dapat berdiri melainkan seperti berdirinya orang yang kemasukan syaitan lantaran (tekanan) penyakit gila. Keadaan 
mereka yang demikian itu, adalah disebabkan mereka berkata (berpendapat), Sesungguhnya jual beli itu sama dengan riba, Padahal Allah telah menghalalkan jual beli dan mengharamkan riba. orang-orang yang telah sampai kepadanya larangan dari Tuhannya, lalu terus berhenti (dari mengambil riba), Maka baginya apa yang telah diambilnya dahulu (sebelum datang larangan); dan urusannya (terserah) kepada Allah. orang yang kembali (mengambil riba), Maka orang itu adalah penghuni-penghuni

neraka; mereka kekal di dalamnya (275). Allah memusnahkan Riba dan menyuburkan sedekah.dan Allah tidak menyukai Setiap orang yang tetap dalam kekafiran, dan selalu berbuat dosa (276). (Qs.Al-Baqarah:275-276)

\section{b. Makna Mufradat}

1) آَّبَيْع , yaitu jual-beli. Al-Quran menggunakan kata $a l-b a ' i$ dan alsyira' untuk pengertian jual dan beli.

2) آَرَّبَّْ sebanyak delapan kali dalam empat surah dan enam ayat, secara literal artinya tambahan (alziyâdah) secara mutlak, baik dalam bentuk benda maupun dalam bentuk pemanfaatan sebagaimana dalam Surah al-Hajj (22): 5 yang di dalamnya terdapat

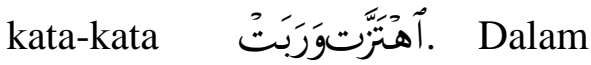
pandangan ahli-ahli tafsir ahkâm dan fuqaha, riba umum diartikan dengan penambahan uang yang diambil oleh pemberi pinjaman yang meminjamkan atau kreditur/penagih (muqridh/dâ'in) dari peminjam/penerima pinjaman atau debitur (muqtaridh/madînmadyûnmudân) sebagai imbalan atas penangguhan waktu pembayaran utang. ${ }^{5}$ Ijtima' Komisi Fatwa Majelis Ulama seIndonesia, memformulasikan riba demikian: "Riba adalah tambahan (al-ziyâdah) tanpa imbalan (bilâ 'iwâdh) yang terjadi karena penangguhan dalam pembayaran (ziyâdah al-ajl) yang diperjanjikan sebelumnya

(usyturitha 
muqaddaman). ${ }^{6} \quad$ Riba pada

umumnya dibedakan dalam dua

macam, meskipun sebagian ulama

ada yang membedakan riba ke

dalam empat macam. Dua macam

riba yang dimaksudkan adalah

riba nasi'ah dan riba fadhl. Riba

nasi'ah atau riba adh'âfan

mudhâ'afah yang juga umum

dikenal dengan sebutan riba

jahiliah, ialah tambahan

pembayaran utang dalam jumlah

tertentu oleh debitur kepada

kreditur sebagai imbalan atas

penangguhan pembayaran utang.

Misalnya, X berutang sejumlah

uang kepada $\mathrm{Y}$, dengan syarat $\mathrm{X}$

akan memberikan tambahan

pembayaran atas utangnya itu

kepada $\mathrm{Y}$ di saat $\mathrm{X}$ membayar

utangnya pada saat jatuh tempo.

Manakala pada waktunya, X

ternyata tidak mampu melunasi

utangnya di saat jatuh tempo,

maka $\quad \mathrm{Y}$ memberikan

perpanjangan waktu pembayaran

utang (pokok maupun tambahan)

kepada $\mathrm{X}$, dengan syarat $\mathrm{X}$ harus menambah lagi pemberian

1975, hlm. 808

${ }^{6}$ MUI, Himpunan Fatwa MUI Sejak tambahan bayaran kepada Y.

Begitulah seterusnya, hingga $\mathrm{X}$

harus terus-menerus membayar

bunga uang itu, kian waktu semakin membengkak dan berlipat-ganda, dalam Alquran diistilahkan dengan adh'afan mudha'afah. Adapun riba fadhl, sebagaimana dapat disimpulkan dari sejumlah hadis Rasulullah Saw. Sebagaimana disimpulkan oleh para fuqaha, ialah riba (tambahan) yang diperoleh atas jual-beli barang yang sama (barter) terutama makanan, di samping uang atau lainnya dengan jenis yang sama dengan syarat ada penambahan. Misalnya, seseorang menjual atau mengutangkan 100 $\mathrm{kg}$ beras dengan syarat orang yang berutang pada waktunya nanti harus membayar/mengembalikan lebih banyak lagi, katakanlah umpamanya $110 \mathrm{~kg}$ beras yang sama (kualitasnya) sebagaimana dibahas dalam berbagai kitab fiqh.

3) مَوْعِظَة yaitu kata-kata nasihat.

4) كَفَّارأَثَيْمِ, Kata kaffâr berasal dari kata kufr, yang secara literal 
artinya ketertutupan sesuatu atau sesuatu yang tertutup (satr alsyai). Itulah sebabnya mengapa situasi malam itu disifati dengan kafir, karena ketertutupan seseorang dari cahaya sehingga menjadi gelap. Demikian pula dengan petani yang dijuluki dengan kafir karena ketertutupan dirinya oleh benih-benih pepohonan atau tumbuhtumbuhan. Kata kaffar di sini digunakan dalam konteks tingkat kekufuran yang lebih dari sekadar kufur, yaitu kufur nikmat dengan sedikit menunaikan kesyukuran. Dengan kalimat lain, kaffâr itu tingkat kekufurannya lebih tinggi dari al-kafur (kekufuran) yang lebih rendah. ${ }^{7}$ Dihubungkan dengan dunia usaha ekonomi dan pemanfaatan harta kekayaan, kaffar itu adalah orang yang usaha ekonominya tidak sepenuhnya halal, seperti halnya orang yang bekerja atau berusaha dengan cara yang halal, tetapi ia tidak mau (enggan) mengeluarkan zakat, infak, dan sedekah dari hartanya

7 Al Raghib al Ashfahani, Mu'jam Mufradat li Alfazh al-Qur'an, hlm. 451-452 itu; sedangkan kaffâr adalah orang yang dalam melakukan usaha ekonomi dan pemanfaatan harta kekayaannya tidak lagi peduli dengan aturan dan etika hukum halal haram, terutama terkait dengan praktik riba.

\section{c. Makna Global}

Ayat 275-281 Surah al-Baqarah di atas, secara umum tetapi tegas memberikan gambaran tentang hukum kehalalan jual-beli dan keharaman riba, dan gambaran karakter atau watak kehidupan pemakan riba (rentenir) yang mirip atau bahkan sama dengan orang yang kesurupan setan atau kesetanan. Penyebab kesetanan pemakan riba itu, justru karena yang bersangkutan tidak lagi bisa membedakan antara jual-beli yang dihalalkan dengan riba yang diharamkan, dan berpendapat bahwa jual-beli itu sama saja dengan riba. Padahal, jual-beli yang dihalalkan jelas sangat berbeda dengan riba yang diharamkan.

\section{d. Sabab al-Nuzul}

Dalam suatu riwayat disebutkan bahwa ayat-ayat di atas, terutama ayat 278-279, diturunkan terkait dengan pengaduan utang-piutang 
ribawi yang sangat zalim antara kalangan Bani al-Mughirah dengan Bani Amr bin Auf dari suku Tsaqif di saat-saat hukum pengharaman riba belum diturunkan. Kisah singkatnya, kaum Bani al-Mughirah, yang ditekan riba oleh Bani Amr, mengadukan persoalannya kepada Gubernur Mekah, 'Attab bin Asyad.

Mereka, Bani al-Mughirah berkata kepada 'Attab bin Asyad: "Kami ini adalah orang-orang yang tetap saja menderita akibat penghapusan riba ini. Karena, kami masih tetap ditagih supaya membayar riba oleh orang lain, padahal kami tidak mau melakukan praktik riba itu demi menaati hukum penghapusan riba.'Kaum Bani Amr memberikan alasan bahwa mereka tetap meminta penyelesaian tagihan riba lama yang sudah terjadi sebelum ayat pengharaman riba diturunkan.Alasannya, dalam kasus ini hukum pengharaman riba tidak berlaku surut.

Menanggapi polemik antara Bani al-Mughirah dan Bani Amr dari suku Bani Tsaqif, lalu Gubernur Mekah, 'Attab bin Asyad menulis surat kepada Rasulullah Saw, dan
Rasulullah Saw pun kemudian memberikan jawaban agar memberlakukan hukum penghapusan riba itu sesuai dengan ayat 278 dan 279 Surah al-Baqarah. Peristiwa ini terjadi setelah Fathu Makkah (Pembebasan kota Mekah) yang terjadi pada bulan Ramadhan, 8 H/Januari $630 \mathrm{M}^{8}$

\section{e. Tafsir Ayat}

Orang-orang yang melakukan muamalah dengan berbasiskan riba, kelak tidak akan bisa bangun ketika dibangkitkan di alam kubur pada hari kiamat, kecuali bagaikan bangun dan jalannya orang-orang yang mabuk dan gila (sempoyongan) karena tidak bisa menahan keseimbangan anggota tubuhnya. Para pelaku dan pemakan riba itu sesungguhnya gelap mata, laksana orang yang kerasukan setan sehingga tidak lagi mengenal rasa keadilan dan keseimbangan dalam berbagi keuntungan atau manfaat yang diperoleh dari dunia kerja dan usaha orang lain. Pemakan riba dalam istilah keseharian masyarakat Indonesia lazim diistilahkan dengan sebutan "lintah darat".

${ }^{8}$ Qamaruddin Shale, dkk. Asbabun Nuzul Latar Belakang Historis Penurunan Ayat-ayat Al Qur'an, hlm. 88-89 
Kondisi para pemakan riba yang berjalan tidak nomal itu, disebabkan mereka tetap kukuh berpendirian bahwa jual-beli (yang dikatakan) itu sama saja dengan riba. Padahal, Allah dengan tegas-tegas menghalalkan jual-beli dan mengharamkan riba. Meskipun keduanya (jual-beli maupun riba) sama-sama mencari keuntungan ekonomi, namun terdapat perbedaan yang mendasar dan signifikan terutama dari sudut pandang cara memperoleh keuntungan di samping tanggung jawab risiko kerugian yang kemungkinan timbul dari usaha ekonomi itu sendiri.

Dewasa ini, sejatinya dunia sudah mengenal baik sejumlah perbedaan di balik beberapa persamaan antara sistem ekonomi dan keuangan konvensional di satu pihak dengan sistem ekonomi dan keuangan Islam di pihak lain. Di antara persamaannya terutama terletak pada motif ekonomi (memperoleh keuntungan ekonomi), sementara perbedaannya terutama terletak pada teknik atau cara-cara, akad, dan objek akadnya sebagaimana telah seringkali dibahas oleh para pakar syariah.
Perbedaan mendasar antara ekonomi dan keuangan syariah dari ekonomi dan keuangan konvensional ialah terutama terletak pada bentuk, objek, dan keberlangsungan akadnya di samping ada beberapa perbedaan lain di luar urusan akad. Bentuk akad, objek akad, dan keberlangsungan akad ekonomi dan keuangan syariah serba mengutamakan asas-asas manfaat, saling menguntungkan dan saling melindungi keberlangsungan akad para pihak.Terutama dari kemungkinan unsur gharar (penipuan) dan maisir (spekulatif) yang merugikan salah satu pihak.Pembahasan panjang lebar tentang perbedaan ekonomi dan keuangan syariah dengan ekonomi dan keuangan konvensional, dewasa ini sudah cukup banyak dibahas para pakar fiqh maupun pakar-pakar ekonomi syariah.

Anehnya, meskipun lembaga keuangan syariah itu dalam banyak hal benar-benar berbeda dari lembaga keuangan - khususnya bank-bank konvensional yang sudah ada, namun masih tetap ada dan banyak orang yang memandang sama saja (tidak 
ada beda) antara ekonomi dan keuangan syariah di satu sisi dengan ekonomi dan keuangan konvensional di sisi yang lain. Persepsi yang mengasumsikan sama antara ekonomi dan keuangan syariah dengan ekonomi dan keuangan konvensional - salah satunya adalah dunia perbankan, ini, tetap bergeming ke tengah-tengah masyarakat luas.

Padahal, Allah itu dengan tegas menyatakan bahwa jual-beli itu prinsipnya adalah halal, dan riba itu pada dasarnya adalah haram.Bunga uang, dalam bentuknya yang mana pun, oleh hampir atau bahkan semua ulama dunia dewasa ini, dinyatakan haram karena diyakini dan terbukti memenuhi unsurunsur riba yang diharamkan itu.

Pembuktian unsur riba, selain dapat diungkap melalui sarana (instrumen) normatif yang mudah diprediksi dan dikalkulasi secara indriawi maupun aqli (keilmuan) yang bersifat matematis, juga sesungguhnya bisa dideteksi dan terutama dirasakan lewat pintu-pintu kehidupan sehari-hari. Jumlah nilai harta yang dimiliki seseorang individu), keluarga, masyarakat, institusi, bahkan oleh bangsa dan negara sekalipun, dapat diprediksi antara nominal, besaran angkanya, maupun dengan dampak positif (keberkahannya) yang bisa dicermati melalui analisis terhadap gejala sosial. Dalam hal ini fenomena kehidupan keluarga, masyarakat, institusi, bahkan bangsa dan negara yang memeraktikkan riba dipastikan kurang/tidak tampak keberkahannya meskipun jumlahnya demikian banyak.Sebaliknya, banyak individu, keluarga, masyarakat, bahkan, bangsa dan negara yang tetap stabil karena keberkahan ekonominya meskipun uangnya tidak terlalu banyak.

Di sinilah letak kelemahan teori dan praktik ekonomi dan keuangan ribawi yang tumbuh membumbung cepat meninggi laksana buih, namun keropos lantaran tidak memiliki basis yang mengakar ke bawah.Lain halnya dengan spirit ekonomi syariah yang berbasiskan keadilan dan pemerataan serta keberkahan sebagaimana tersimbolkan dalam ayat-ayat zakat, infak, dan sedekah yang sebagian penempatannya dalam 
Alquran, justru disandingkan dengan ayat-ayat tentang penghalalan jualbeli dan pengharaman riba.

\section{f. Istinbat Hukum}

Dari

$$
\text { ayat-ayat yang }
$$

mengharamkan riba di atas, dapatlah diistinbatkan hukumnya sebagai berikut.

1) Allah menghalalkan hukum jualbeli dan mengharamkan riba.

2) Riba itu hukumnya haram secara mutlak, baik sedikit maupun banyak.

3) Riba yang diharamkan secara total itu, termasuk ke dalam tindak pidana sosial kemasyarakatan dan sekaligus kejahatan keagamaan yang sangat berbahaya.

4) Riba tergolong ke dalam perbuatan atau tindakan dosa besar yang semua pelakunya diancam dengan hukuman akhirat, berupa siksaan neraka yang sangat dahsyat.

\section{g. Hikmah Pengharaman Riba}

Praktik ribawi, baik riba fadhl maupun riba nasi'ah, sesungguhnya sangat merusak kehidupan umat manusia.Baik dari sudut pandang individu para pelakunya, maupun dari sisi pandang sosial kemasyarakatan pada umumnya, dan sosial ekonomi dan keuangan pada khususnya. Dari sisi pelakunya secara individu, para pelaku riba benar-benar gelap mata, lantaran kesurupan setan sehingga tidak lagi mengenal perikemanusiaan dalam memeras (mengeksploitasi) orang lain yang notabene menjadi "mitra" usaha/bisnisnya. Lihat saja praktik lintah darat yang memeras keuntungan dengan cara apa pun. Praktik debt collector yang sering terjadi di masyarakat lemah (tidak berdaya) merupakan contoh konkretnya.Kata-kata kasar dan tindakan brutal debt collector yang acapkali terjadi, bahkan tidak jarang menghilangkan nyawa orang lain, sangat berlawanan dengan penawaran sopan membuai yang dilakukan orang-orang marketing sebelum terjadi transaksi utang-piutang (kredit).Persis bagaikan ular berbisa yang berkulit indah warna-warni, namun demikian berbahaya, sampai membawa maut tatkala terkena dengan bisanya yang sangat beracun.

Bahaya riba dari sudut pandang sosial kemasyarakatan, terlihat dan terutama terasa jelas mustahil bisa 
menciptakan hubungan timbal-balik (harmonis) antara pemilik modal yang kapitalis dengan sikap dan wataknya yang serba sesuka-suka dan semena-mena di satu pihak, dengan para nasabah yang selalu merasa tertekan atau bahkan ditekan dan tidak berdaya meski terkesan pasrah.Sistem riba yang sangat kapitalistik itu, selalu menciptakan suasana disharmoni kalau tidak tepat dikatakan permusuhan dan saling membenci di samping sikap "cuekisme" bahkan sumpah serapah antara sesama relasi sendiri.Kalaupun ekonomi ribawi itu membuat jejaring sosial yang tampak menyenangkan segelintir orang, namun dalam praktiknya tetap saja rapuh karena bukan terlahir atas dasar pertimbangan keadilan dan pemerataan, apalagi

keberkahan.Melainkan lebih disandarkan pada motivasi pengelabuan opini berdasarkan pendekatan segelintir orang yang dijadikan sebagai pilar-pilar penyangga kepentingan ekonomi dan keuangannya yang dimiliki segelintir orang/pihak itu.
Bahaya riba dari sudut pandang ekonomi dan keuangan, juga jelas terlihat dan terutama terasakan tatkala ekonomi kapitalis yang ribawi itu, selalu memilah masyarakat ekonomi ke dalam dua kelompok masyarakat ekonomi, yaitu kelompok hedonis (thabaqah mutrifah) yang hidup dengan serba nikmat dan serba mewah di satu pihak, dengan kelompok miskin dan papa (thabaqah mu'dimah) yang hidup dalam kondisi serba butuh, kekurangan, dan tertekan. Akibatnya, selalu saja timbul ketegangan dan konflik sosial antara dua kelompok ini lantaran kejahatan riba yang mengonsentrasikan harta kekayaan dan keuangan pada segelintir orang (kekuasaan dan perusahaan), dengan mengabaikan masyarakat yang jumlahnya jauh lebih banyak lagi.Kondisi sosial ekonomi dan keuangan yang ribawi-kapitalistik atau kapitalistik yang ribawi ini, kapan saja dan di mana saja bisa menimbulkan benih-benih atau bibit bibit konflik sosial yang siap meledak kapan saja dan di mana saja karena sarat dengan tekanan dan fitnah.Pada era modern sekarang ini, 
dengan mudah kita bisa menyaksikan kebobrokan teori ekonomi kapitalis yang sarat dengan riba itu.Sebagaimana tengah dialami oleh negara-negara yang sebelumnya dikategorikan sebagai negara-negara maju.

\section{KESIMPULAN}

Riba diharamkan dalam setiap transaksi maupun aktivitas ekonomi dalam sistem ekonomi Islam. Dari fakta-fakta yang telah dijelaskan di atas telah terbukti baik dari ayat-ayat Al Qur'an maupun bukti-bukti empiris bahwa dengan menerapkan riba dalam aktivitas ekonomi telah menimbulkan kehancuran ekonomi, kemiskinan, inflasi, krisis ekonomi dan perusakan lingkungan. Karena itu aktivitas ekonomi yang dilandaskan pada prinsip bunga atau riba perlu dihilangkan. Untuk menghilangkan praktek riba dalam aktivitas ekonomi maka perlu dilakukan hal-hal sebagai berikut:

1. Optimalisasi Sosialisasi sistem ekonomi Islam. Seperti pendayagunaan zakat, infak dan shadaqah.

2. Adanya kemauan politik (politic will) dari pemerintah untuk menerapkan sistem ekonomi Islam.

3. Memperbanyak dan mempermudah pembentukan lembaga keuangan non riba ( Bank Islam, BPR Islami, BMT dll).

4. Memberikan bantuan modal bagi masyarakat dengan sistem bagi hasil.

\section{DAFTAR PUSTAKA}

Qadir, Abdurrahman. 1998. Zakat dalam Dimensi Mahdhah dan Sosial. PT Raja Grasindo Persada, Jakarta.

al-Jurjani, Ali bin Muhammad, Kitab alTa,rifāt, Beirut: Dār al-Kutub al-,,Ilmiyyah, t.tt.

Al-Jaziri , Abdurrahman, Kitāb al-Fiqh „alā Madzāhib al-Arba,,ah, Beirut: Dār al-Fikr, t.t

Saefuddin Muflih Ahmad, 1986. Pengelolaan Zakat ditinjau dari Aspek Ekonomi, Bontang, Badan Dakwah Islamiyah, LNG, 1986, hal.99

Biro Pusat Statistik. 1995. Statistik 50 Tahun Indonesia Merdeka.

Chapra, Umer M. 2001.Masa Depan Ilmu Ekonomi. Gema Insani Press, Jakarta

Hafdhudin Didin. 2003. Mengutamakan Cara dan Proses yang Benar. Ekonomi Syariah Dalam Sorotan. Yayasan Amanah, MES dan PNM.

Diwany, Tarek El. 2005. The Problem With Interest. Terjemahan Amdiar Amir dan Ugi Suharto. Akbar Media Eka Sarana

Ragilia Widuri Rini. 2009. Indonesia keluar Krisis Paling Awal. Media Indonesia 15 Agust 2009.

Mankiw, N. Gregory. 2007. Makro Ekonomi. Edisi Keenam. Penerbit Erlangga. Jakarta, Indonesia.

Parkin Michael. 1997. Economy Macro (Power Point). Web Site. Michael Parkin. September 1997. 
Kahf Monzer. 1995. Ekonomi Islam, Telaah Analitik Terhadap System Ekonomi Islam, Yogyakarta, Pustaka Pelajar.

Mustaq. 2001. Etika BIsnis Dalam Islam.Pustaka al-Kautsar. Jakarta.

al-Shabuni Muhammad Ali, Rawā"i, alBayān Tafsīr Ayāt al-Ahkām min al-Qur"ān, jilid 1, Beirut: Dār al-Fikr, t.tt

Muttaqin M. Zainal. 1997. Kewajiban Menjadi Muzakki. Makalah pada seminar zakat antara cita dan fakta, Bogor, Januari 1997.

Smick, David.M. 2008. The World is Curved. Portofolio New York.Terjemahan Bahasa Indonesia oleh Daras Books. 2009. 